\title{
Article \\ Validity and Reliability of the Caregiver Strain Index Scale in Women during the Puerperium in Spain
}

\author{
David Feligreras-Alcalá, María del Pilar Cazalilla-López (D), Rafael del-Pino-Casado *(D) and Antonio Frías-Osuna
}

\section{check for}

updates

Citation: Feligreras-Alcalá, D.; Cazalilla-López, M.d.P.;

del-Pino-Casado, R.; Frías-Osuna, A.

Validity and Reliability of the

Caregiver Strain Index Scale in

Women during the Puerperium in

Spain. Int. J. Environ. Res. Public

Health 2021, 18, 3602. https://

doi.org/10.3390/ijerph18073602

Academic Editor: M.Carmen Míguez Varela

Received: 4 February 2021

Accepted: 27 March 2021

Published: 30 March 2021

Publisher's Note: MDPI stays neutral with regard to jurisdictional claims in published maps and institutional affiliations.

Copyright: (C) 2021 by the authors Licensee MDPI, Basel, Switzerland. This article is an open access article distributed under the terms and conditions of the Creative Commons Attribution (CC BY) license (https:// creativecommons.org/licenses/by/ $4.0 /)$
Department of Nursing, Faculty of Health Sciences, University of Jaén, 23071 Jaén, Spain; dfa00001@red.ujaen.es (D.F.-A.); mpc10008@red.ujaen.es (M.d.P.C.-L.); afrias@ujaen.es (A.F.-O.)

* Correspondence: rdelpino@ujaen.es; Tel.: +34-953-212021

\begin{abstract}
Background: The objective of this study is to determine the validity and reliability of the Caregiver Strain Index (CSI) for women during the postpartum period. Methods: This is a validation study of a measurement instrument. This study includes 212 women over the age of 19 who gave birth from March to September 2019 in Maternal and Child Hospital of Jaén (Spain). The items of the CSI were adapted for newborn care. Content validity was measured by five experts, calculating the index of agreement (Aiken's V). Criterion validity was assessed by correlations with scores of other tools that measure constructs related to burden (Edinburgh Postpartum Depression Scale, State-Trait Anxiety Questionnaire, SOC-13 and Duke-UNC-11). Construct validity was determined by the known-groups method. Internal consistency was measured using Cronbach's Alpha, and stability was analysed using the intraclass correlation coefficient (ICC). Results: Regarding content validity, an Aiken's V of 1.00 ( $p=0.032)$ was obtained. Regarding criterion validity, the correlation analyses showed statistically significant coefficients between the scores of the questionnaire and those of the sense of coherence $(\mathrm{r}=-0.447, p<0.001)$, depressive symptoms $(\mathrm{r}=0.429, p<0.001)$, social support (rho $=-0.379, p<0.001)$ and anxiety symptoms $(\mathrm{r}=0.532, p<0.001)$. The known-groups method showed statistically significant differences in the mean of subjective burden between the groups (depressive symptoms, anxiety symptoms, sense of coherence and social support). The total scale obtained a Cronbach's alpha value of 0.710 . The ICC was 0.979 . Conclusions: The adapted CSI is a valid and reliable screening tool for the subjective burden in women during the puerperium. The adapted CSI can play an important role as a guide to detect the subjective burden in women during the puerperium.
\end{abstract}

Keywords: subjective burden; caregiver strain index; puerperium; postpartum depression; validity; reliability

\section{Introduction}

The process of pregnancy, childbirth and puerperium constitutes an important event in a woman's life, where she faces significant changes in her cognitive, behavioural and social spheres [1]. Sometimes, this process can be perceived as stressful [2,3], which can lead to an increase in the subjective burden on newborn care $[4,5]$. The subjective burden has been defined based on the model of the General Theory of Stress. In this model, the caregiver must face certain stressors, and the caregiver's response will be conditioned by psychological processes that include emotional impact, the perception of social support and coping strategies [6]. On the other hand, according to the Lazarus and Folkman Stress Transactional Model, the consequences of stress are measured according to the way in which caregivers perceive, evaluate and manage the care process [7].

Thus, subjective burden is considered a state characterised by stress, fatigue and difficulties in adapting to the role of caregiver, caused by a negative evaluation of the caregiver's situation that threatens their physical, psychological and emotional health [8]. The term subjective burden refers to the assessment by the caregiver that the care situation 
surpasses the skills that the caregiver possesses to deal with the situation adequately [9]. In this sense, it can also refer to the perception that women have of feeling bewildered, burdened, trapped, resentful and excluded [9]. The objective burden is considered to reflect the daily and practical aspects of the provision of care that capture quantitative dimensions of the caregiver function, such as the level of care needs and the hours of care provision [10].

The presence of caregiver burden can be associated with the appearance of disorders such as depressive symptoms [11] and anxiety [12]. In this context, we could consider the puerperium as a stage in which the subjective burden is significant. Some authors affirm that women with high levels of care burden could have a greater tendency to develop health problems during the puerperium. The investigation of factors associated with the presence of negative consequences related to the subjective burden during the postpartum period, takes on special importance in the early detection and prevention of these factors, such as anxiety [13] or depressive symptoms [14].

Several studies have been carried out to explore the possible association of subjective burden and depressive symptoms in caregivers of the elderly [15-17]. In relation to the presence of postpartum depression (PPD), there are studies that suggest that a higher level of subjective burden regarding newborn care could be associated with a higher level of stress and an increase in depressive symptoms [18,19]. Similarly, Leung et al. [14] show the importance of stress with newborn care as an important predictor of the appearance of PPD. Postpartum depression has a prevalence of $12-13 \%$ at 6 weeks of postpartum in industrialised countries [20,21]; in Spain, the studies carried out place it between 10\% and $23 \%$ [22-25].

In this sense, it would be especially useful to have a measurement instrument adapted to women in the puerperium, which allows a more specific assessment of the construct of the subjective burden of care in this population. The Caregiver Strain Index (CSI) is an instrument designed to measure the subjective burden of caregivers of dependent family members. It is a simple scale, which requires little time to complete, and offers the possibility of an empathic approach towards the caregiver [26]. Robinson validated this instrument in 1983 in the United States (U.S.) in caregivers of patients, after hospital discharge, with atherosclerotic heart disease or with implantation of a hip prosthesis [27].

The CSI scale has been widely used and adapted to diverse populations, cultural contexts and languages [28-30]. In the Spanish population, this scale has been validated with caregivers of patients with chronic, oncological and acute pathologies that required home care [31] and in caregivers of patients diagnosed with dementia [26], with an acceptable internal consistency (Cronbach's alpha of 0.80 ). This scale is made up of 13 items with a dichotomous response (yes/no) in the context of a semistructured interview whose score ranges from 0 to 13 points [31]. However, no validation study has been found to prove its use in women during the puerperium.

Thus, the adaptation of this CSI scale would have enormous clinical applicability. On the one hand, it would allow the detection of subjective burden in these types of caregivers and early identification of women with high levels of subjective burden in care and therefore with a tendency towards postpartum depression or anxiety, among other associated complications. On the other hand, it would allow improving the treatment of these health problems with a more specific and individualised approach. Thus, this scale would become a useful tool for detecting the subjective burden in care in puerperal women. The aim of this study is to determine the validity and reliability of the CSI in women during the puerperium.

\section{Materials and Methods}

\subsection{Questionnaire Adaptation}

To carry out this work, the items of the CSI scale (Spanish version validated by López Alonso et al. [31]) were adapted for newborn care, after consensus of a working group formed by the authors of the present study. 


\subsection{Content Validation by Experts}

Content validity was measured by five experts from the Department of Nursing of the University of Jaén, with extensive academic experience in the study area and other complementary areas. The index of agreement that should exist to determine this validity was established using the Validity Coefficient V of Aiken [32,33].

\subsection{Pilot Test}

A pilot test was conducted to determine the comprehension and applicability of the scale through semistructured interviews with 40 women during the puerperium, during which they were asked if they adequately understood the items of the scale. Subsequently, an analysis and interpretation of the responses obtained was carried out, identifying possible aspects that were not well understood.

\subsection{Clinical Validation}

Clinical validation was carried out through a descriptive cross-sectional study in women during the puerperium in the province of Jaén, Spain, using the data collected by Feligreras et al. [34]. Two-hundred-and-twelve women who gave birth at the Maternal-Infant Hospital of Jaén were recruited by random sampling between March and September 2019.

The sample size analysed allows us to affirm, for a 13-item scale, that the calculated Cronbach's alpha is significantly higher than the value of 0.7 , with a statistical power of $80 \%$ and a significance level of $5 \%$, taking the value of the null hypothesis at 0.6 (calculations performed with PASS 11). The aforementioned sample size also allows us to detect differences of at least 1.1 points out of $13(8.5 \%)$ with a power of $80 \%$ and a significance level of $5 \%$, taking as a reference a standard deviation of 2.76 (calculations made with EpiDat 4.2).

The exclusion criteria were age equal to or less than 19 years, previous and/or current personal history of psychiatric pathology, serious illness or death of the newborn, not understanding the Spanish language, not accepting participation in the study or not signing the informed consent.

For the characterisation of the sample, the following variables were collected: age, marital status, educational level, employment situation, family income, pregnancy search, number of pregnancies, type of delivery, sex of the newborn and family history of psychiatric pathology.

\subsubsection{Criterion Validity}

Criterion validity was assessed by correlations with the scores of other instruments that measure constructs related to subjective burden. These measurement instruments were the Edinburgh Postpartum Depression Scale (EPDS) for the depression construct [35], the state-trait anxiety scale STAI for the anxiety construct [36], the Antonovsky SOC scale for the construct of sense of coherence [37] and the Duke-UNC-11 scale for the construct of social support [38].

Depressive symptoms were measured using the EPDS [35]. This scale is used to detect depressive states in the postpartum period. It is a self-administered scale of 10 items, with four possible response alternatives, scored from 0 to 3 , depending on the severity of symptoms. Scores range from 0 to 30 points (proportional to the level of depressive symptoms). A cut-off point, equal to or greater than 10 points, is considered adequate to detect depressive symptoms in this period, with a sensitivity of $79 \%$, a specificity of $95 \%$ and a positive predictive value of $63 \%$ [25]. Its use is recommended in the first 6 weeks of postpartum to ensure correct screening for depressive symptoms in puerperium, according to the Ministerio de Sanidad, Consumo y Bienestar Social of Spain [39]. It is validated and widely applied in Spain [25].

Anxiety was measured by STAI state-trait's anxiety questionnaire [36], a self-administered instrument that measures two independent concepts of anxiety: On the one hand, anxiety as a state is referred to as a transient emotional condition; on the other hand, anxiety as a trait 
is described as a relatively stable anxious propensity. In the development of this research, anxiety status has been evaluated as a specific measure of anxiety during this study period. This subscale consists of 20 items, with 4-point, Likert responses (proportional to intensity of anxiety). Total subscale scores range from 0 to 60 points, with the 75th percentile recommended as a cut-off point in adult women [36]. This questionnaire is validated in the Spanish population, presenting a Cronbach's alpha coefficient of 0.94 [40].

The sense of coherence was collected using the SOC-13 Sense of Coherence scale [37]. This scale assesses three dimensions of sense of coherence: compressibility, manageability and significance, which are closely related. It consists of 13 items that are answered on a Likert scale with seven scores, ranging from 1 (always) to 7 (never), where a higher score indicates a greater sense of coherence. This scale is validated in the Spanish population, presenting a Cronbach's alpha of 0.80 [41].

Perceived social support was measured by the Duke-UNC-11 questionnaire [38], a selfadministered instrument that measures social support both in its affective dimension (i.e., referring to expressions of love, appreciation, sympathy or belonging) and its confidential dimension (i.e., that through which people can receive information, advice or guidance). It consists of 11 items along with a 5-point, Likert response scale, ranging from 1 (Much less than I want) to 5 (As much as I want). Scoring for the total questionnaire ranges from 11 to 55 points (directly proportional to the level of perceived social support). This questionnaire has been validated in the Spanish population with adequate psychometric properties (e.g., Cronbach's alpha coefficient of 0.93) [42].

These measurement instruments were chosen because there is sufficient scientific evidence that relates the subjective burden with a higher incidence of depression in postpartum women [19], with higher levels of anxiety in caregivers of patients at the hospital level [43], with a lower sense of coherence in caregivers of dependent elderly relatives [11] and with less social support in caregivers of adults with schizophrenia [44].

We used the Pearson bivariate correlations between the scores of the adapted CSI and the scores of the questionnaires of the variables that fulfilled the assumptions of normality (depressive symptoms, anxiety and sense of coherence), and bivariate Spearman correlations in social support; this was a similar analysis to that carried out in the validation of the CSI in our country [31].

\subsubsection{Construct Validity}

To evaluate the construct validity, the known-groups method was performed. Difference of means tests were carried out using the Student's t-test and the magnitude of the effect was measured using Cohen's d. The hypotheses tested were, according to the scientific literature on subjective burden, (1) the greater the presence of depressive symptoms, the higher the subjective burden level in women in the puerperium [19]; (2) the greater the presence of anxiety symptoms, the higher the level of subjective burden in women in the puerperium [43]; (3) the lower the sense of coherence, the higher the level of subjective burden [11]; and (4) the less social support, the higher the level of subjective burden in women in the puerperium [44]. The cut-off points proposed by each author in the scales used for depressive symptoms, anxiety symptoms and social support were used, whereas we used the median in the case of the sense of coherence.

\subsubsection{Reliability Internal Consistency}

To determine internal consistency, Cronbach's alpha was analysed. For the assessment of this coefficient, the recommendations of George and Mallery [45] were used, who show that an acceptable internal consistency has values greater than 0.70 . 


\section{Stability (Test-Retest)}

Stability was measured with the intraclass correlation coefficient (ICC). To do this, the scale was administered again after one week to a sample of 20 women. Following the Fleiss recommendations [46], values above 0.75 represent excellent reliability.

To carry out the analyses, the level of statistical significance was set at 0.05 . The relationships between the proposed variables were examined with the help of the SPSS v. 22.0 (IBM International Business Machines Corporation, Armonk, NY, USA) program.

\section{Results}

\subsection{Definitive Questionnaire and Pilot Test}

In adapting the questionnaire, the examples that the authors provided in the original version for chronic, oncological and acute patients requiring home care were replaced with examples related to newborn care. In addition, item number 10 has been adapted to a newborn care situation. The final questionnaire (the CSI adapted to newborn care) is showed in Appendix A, and its translation into English is presented in Appendix B.

Regarding content validity, the five experts obtained a Validity Coefficient V of Aiken of $1.00(p=0.032)$ for the total of the items of the questionnaire [32,33]. Therefore, according to the recommendations of Aiken, we can show the maximum agreement among the experts, avoiding random coincidences. There were no changes derived from the performance of the content validity analysis in the questionnaire.

After conducting the pilot test, an adequate understanding of the item statements was verified.

\subsection{Clinical Validation}

Descriptive data of the sample are shown in Table 1. The mean age of the participating women was 32 years, with a minimum age of 19 and a maximum age of 47 years. Most of the women were married (78.3\%) with an active employment situation, self-employed or employed $(69.4 \%)$. Forty-seven percent of the participants had university studies, and $90.1 \%$ of the women reported that the pregnancy had been wanted.

Table 1. Description of the studied sample.

\begin{tabular}{|c|c|c|c|c|}
\hline Variables & & $n(\%)$ & M (SD) & CI 95\% \\
\hline Age & & & $32.670(4.58)$ & $32.06-33.26$ \\
\hline \multirow[t]{4}{*}{ Marital Status } & Single & $8(3.8)$ & & $1.40-6.60$ \\
\hline & Married & $166(78.3)$ & & $72.60-83.50$ \\
\hline & With couple & $35(16.5)$ & & $11.80-21.70$ \\
\hline & Separated or divorced & $3(1.4)$ & & $0.00-3.30$ \\
\hline \multirow{6}{*}{ Education level } & Primary & $18(8.5)$ & & $4.70-12.30$ \\
\hline & Secondary & $21(9.9)$ & & $6.10-14.20$ \\
\hline & High School & $12(5.7)$ & & $2.40-9.00$ \\
\hline & FP Middle degree & $36(17.0)$ & & $12.30-22.20$ \\
\hline & FP Higher degree & $24(11.3)$ & & $7.10-15.60$ \\
\hline & University & $101(47.6)$ & & $41.00-54.20$ \\
\hline \multirow[t]{5}{*}{ Employment situation } & Student & $3(1.40)$ & & $0.00-3.30$ \\
\hline & Active or own account & $39(18.4)$ & & $13.70-23.60$ \\
\hline & Asset & $108(50.9)$ & & $43.90-57.10$ \\
\hline & Unemployed & $47(22.2)$ & & $16.50-27.80$ \\
\hline & Domestic work & $15(7.1)$ & & $4.20-10.80$ \\
\hline \multirow[t]{8}{*}{ Family income } & $<$ from $500 €$ & $1(0.5)$ & & $0.00-1.40$ \\
\hline & From 500 to $<1000 €$ & $27(12.7)$ & & $8.50-17.00$ \\
\hline & From 1000 to $<1500 €$ & $60(28.3)$ & & $22.60-34.40$ \\
\hline & From 1500 to $<2000 €$ & $54(25.5)$ & & $19.80-31.60$ \\
\hline & From 2000 to $<2500 €$ & $29(13.7)$ & & $9.00-17.90$ \\
\hline & From 2500 to $<3000 €$ & $28(13.2)$ & & $9.00-17.90$ \\
\hline & From 3000 to $<5000 €$ & $10(4.7)$ & & $1.90-8.00$ \\
\hline & $>$ from $5000 €$ & $3(1.4)$ & & $0.0-3.30$ \\
\hline
\end{tabular}


Table 1. Cont.

\begin{tabular}{|c|c|c|c|c|}
\hline Variables & & $n(\%)$ & M (SD) & CI 95\% \\
\hline \multirow[t]{2}{*}{ Pregnancy wanted } & Yes & $191(90.1)$ & & $85.80-93.90$ \\
\hline & No & $21(9.9)$ & & $6.10-14.20$ \\
\hline No. of pregnancies & & & $1.835(0.986)$ & $1.71-1.97$ \\
\hline \multirow[t]{3}{*}{ Type of delivery } & Eutocic & $141(66.5)$ & & $60.80-73.10$ \\
\hline & Instrumental & $32(15.1)$ & & $10.40-20.30$ \\
\hline & Caesarean section & $39(18.4)$ & & $13.20-23.60$ \\
\hline \multirow[t]{2}{*}{ Sex of newborn } & Male & $112(52.8)$ & & $46.20-59.90$ \\
\hline & Female & $100(47.2)$ & & $40.10-53.80$ \\
\hline \multirow{2}{*}{ Family history of psychiatric pathology } & Yes & $13(6.1)$ & & $3.30-9.40$ \\
\hline & No & 199 (93.6) & & $90.60-96.70$ \\
\hline
\end{tabular}

Source: self-made.

The minimum CSI score obtained was 0 and the maximum score was 13 , the mean score being 5.23 (SD: 2.76). The correlations between the different items and the overall result were higher than 0.2 in all cases [47], and the ICC for the agreement between items was 0.71 [48].

\subsection{Criterion Validity}

The correlation analyses showed statistically significant coefficients between the scores of the adapted CSI questionnaire and those of sense of coherence $(\mathrm{r}=-0.447, p<0.001)$, depressive symptoms $(\mathrm{r}=0.429, p<0.001)$, social support (rho $=-0.379, p<0.001)$ and anxiety symptoms $(\mathrm{r}=0.532, p<0.001)$.

\subsection{Construct Validity}

We proceeded to perform the known-groups method. There were statistically significant differences in the mean of subjective burden between the groups analysed: (1) presence or not of depressive symptoms (6.68 vs. 4.69 ; d: $0.77 ; 95 \% \mathrm{CI}: 0.45,1.08)$, (2) presence or absence of anxiety symptoms (7.08 vs. 4.51 ; d: 1.02 ; $95 \%$ CI: $0.71,1.34)$, (3) presence or not of sense of coherence ( 4.28 vs. $6.21 ; \mathrm{d}:-0.76 ; 95 \% \mathrm{CI}:-1.04,-0.48)$ and (4) presence or not of social support ( 4.88 vs. $7.00 ; \mathrm{d}:-0.81 ; 95 \% \mathrm{CI}:-1.18,-0.43)$ (Table 2 ).

Table 2. Differences in means of subjective burden in the subgroups of women with and without depressive symptoms, anxiety, sense of coherence and social support.

\begin{tabular}{ccccc}
\hline Variable & Mean (SD) & Significance & Cohen's d & 95\% CI \\
\hline Depressive symptoms & Yes: 6.68 (2.72) & $p<0.0001$ & 0.77 & $(0.45,1.08)$ \\
& No: $4.69(2.58)$ & & & \\
Anxiety & Yes: $7.08(2.62)$ & $p<0.0001$ & 1.02 & $(0.71,1.34)$ \\
& No: $4.51(2.47)$ & & & \\
Sense of coherence & Yes: $4.28(2.56)$ & $p<0.0001$ & -0.76 & $(-1.04,-0.48)$ \\
& No: $6.21(2.62)$ & & & \\
Social support & Yes: $4.88(2.67)$ & $p<0.0001$ & -0.81 & $(-1.18,-0.43)$ \\
& No: $7.00(2.52)$ & & & \\
\hline
\end{tabular}

Source: self-made.

\subsection{Reliability}

In relation to internal consistency, Cronbach's alpha was determined for the total scale, obtaining a value of 0.710 (acceptable internal consistency). Regarding the stability of the test, the Intraclass Correlation Coefficient (ICC) was measured, reaching a value of 0.979 (95\% CI = 0.949-0.992) (excellent stability).

\section{Discussion}

In this study, we presented the adaptation and validation of the CSI in order to measure the subjective burden in women during the puerperium. The CSI adapted to newborn 
care was quick and easy to administer in the population studied. The study participants adequately understood each of the items both in the pilot test and in the final application of this measurement instrument. The adapted scale obtains adequate psychometric properties at the level of criterion validity and construct validity, internal consistency and stability, which shows an adequate validity and reliability of the measurement instrument.

Criterion validity was assessed using bivariate correlations with scores from other instruments that measured constructs related to subjective burden. López-Alonso et al. [29] in the CSI validation in the Spanish population carried out a similar analysis, correlating the subjective burden with other similar areas included in the original validation of the scale.

Regarding the construct validity, we confirmed all the hypotheses tested in the knowngroups method, which reinforces the construct validity of the instrument in measuring subjective burden in women during the puerperium.

Regarding internal consistency, we can find some coincidences of our study with other studies on CSI in other types of caregiver populations. Thus, Ugur et al. [49] carried out an adaptation of this scale in the Turkish population, finding a Cronbach's alpha value of 0.77 . Ramasamy et al. [50] in Malaysia obtained an internal consistency of 0.75 . The Chinese version [51] showed high reliability with a Cronbach's alpha of 0.91 , the same result as that obtained in the Portuguese population [52]. In our study, we obtained an internal consistency of 0.710 . Therefore, our results in this regard are similar to those available in the literature.

Regarding the measurement of stability, the adapted CSI was administered again one week after the first measurement in the puerperium; the time elapsed between both applications should not be too long (variation of the phenomenon studied) nor too short (learning effect) [53]. The ICC for test-retest reliability was 0.979 , higher than the 0.88 obtained by Thornton and Travis in the modified version of the CSI [54]. Both in the original validation of the CSI [27] and in the validation of the CSI in our country [31], test-retest reliability was not calculated. Following Fleiss [46], values above 0.75 show excellent reliability. These data confirm the stability of the CSI adapted to newborn care.

To date, in the scientific literature there was no validation of the CSI scale in women during the puerperium. In this way, with the adaptation and validation of this scale, we obtain a measurement instrument that has enormous clinical applicability. This scale allows us to measure in a more specific way the construct of the subjective burden of care in women during the puerperium. In this sense, the adapted CSI in the puerperal population offers us the possibility of early diagnosis of women with high levels of subjective burden and, therefore, with a possible higher risk of developing PPD or anxiety (among other associated complications). Therefore, this scale constitutes a useful tool for detecting the subjective burden of newborn care in puerperal women.

The study has the limitation that the entire sample obtained for the study comes from a single hospital centre. Another limitation is that the study does not fully comprise some perinatal factors and circumstances associated with delivery, which might affect the evaluation of the criterion validity.

\section{Conclusions}

According to the findings obtained in this research, the CSI adapted to newborn care is a valid and reliable screening tool for the subjective burden in women during the puerperium. This study can play an important role as a guide to detect the subjective burden in women during the puerperium, in order to plan preventive and health promotion actions in those women with a risk profile of subjective burden in newborn care.

Author Contributions: Conceptualisation, D.F.-A., M.d.P.C.-L., R.d.-P.-C. and A.F.-O.; methodology, D.F.-A., M.d.P.C.-L., R.d.-P.-C. and A.F.-O.; validation, D.F.-A.; and M.d.P.C.-L.; formal analysis, R.d.-P.-C. and A.F.-O.; investigation, D.F.-A., M.d.P.C.-L. and R.d.-P.-C.; resources, R.d.-P.-C.; data curation, D.F.-A., M.d.P.C.-L., R.d.-P.-C. and A.F.-O.; writing-original draft preparation, R.d.-P.-C. and A.F.-O.; writing — review and editing, D.F.-A., R.d.-P.-C. and A.F.-O.; visualisation, R.d.-P.-C. and 
A.F.-O.; supervision, R.d.-P.-C. and A.F.-O.; project administration, R.d.-P.-C. All authors have read and agreed to the published version of the manuscript.

Funding: This research received no external funding.

Institutional Review Board Statement: This study was approved by the Jaén Research Ethics Committee of the SSPA (Andalusian Public Health System) on April 5, 2017 with code 0262-M1-17. Informed consent was requested as a guarantee of respect for the bioethical principle of Autonomy, in accordance with the provisions of Spanish Law 41/2002, of 14 November, regulating the basic autonomy of the patient and rights and obligations regarding information and clinical documentation. The study was carried out in accordance with state legislation and the principles established in the Declaration of Helsinki of 1964. The confidentiality and privacy of the data obtained were guaranteed, in accordance with Spanish Organic Law 15/1999, of 13 December, Protection of Personal Data. The possibility of the participants both to refuse to participate and to abandon the study at any time was indicated verbally and in writing.

Informed Consent Statement: Informed consent was obtained from all subjects involved in the study. Written informed consent has been obtained from the patients to publish this paper.

Data Availability Statement: The data presented in this study are available on request from the corresponding author. The data are not publicly available due to their containing information that could compromise the privacy of research participants.

Acknowledgments: The authors would like to thank the women interviewed for their participation in the study.

Conflicts of Interest: The authors declare no conflict of interest.

\section{Appendix A. Caregiver Strain Index Adapted to Newborn Care (In Spanish)}

\begin{tabular}{lll}
\hline Ítems & Sí $=\mathbf{1}$ & No $=\mathbf{0}$ \\
\hline $\begin{array}{l}\text { 1. Tiene trastornos de sueño (p. ej., porque su hijo/a se despierta por } \\
\text { la noche). }\end{array}$ & \\
\hline
\end{tabular}

2. Es un inconveniente (p. ej., porque el cuidado consume mucho tiempo o se tarda mucho en proporcionarlo).

3. Representa un esfuerzo físico.

4. Supone una restricción (p. ej., porque el cuidado limita el tiempo libre).

5. Ha habido modificaciones en la familia (p. ej., porque el cuidado ha roto la rutina o no hay intimidad).

6. Ha habido cambios en los planes personales (p. ej., se tuvo que rechazar un trabajo o no se pudo ir de vacaciones).

7. Ha habido otras exigencias de mi tiempo (p. ej., por parte de otros miembros de la familia).

8. Ha habido cambios emocionales (p. ej., causa de fuertes discusiones).

9. Algunos comportamientos son molestos (p. ej., el llanto, los despertares nocturnos ... ).

10. Es molesto darse cuenta de que la situación ha cambiado tanto comparada con la de antes.

11. Ha habido modificaciones en el trabajo (p. ej., a causa de la necesidad de dedicar tiempo para el cuidado).

12. Es una carga económica.

13. Nos ha desbordado totalmente (p. ej., por la preocupación sobre cómo cuidar a su hijo/a).

Puntuación total (contar respuestas afirmativas) 
Appendix B. Caregiver Strain Index Adapted to Newborn Care (English Translation of the Spanish Version)

\begin{tabular}{l}
\hline Items \\
\hline 1. Sleep is disturbed (e.g., because your child wakes up at night). \\
\hline 2. It is inconvenient (e.g., because helping takes so much time or it is a long \\
drive over to help). \\
\hline 3. It is a physical strain. \\
\hline 4. It is confining (e.g., helping restricts free time). \\
\hline 5. There have been family adjustments (e.g., because helping has disrupted \\
routine or there has been no privacy). \\
\hline 6. There have been changes in personal plans (e.g., had to turn down a job \\
or could not go on vacation). \\
\hline 7. There have been other demands on my time (e.g., from other \\
family members). \\
\hline 8. There have been emotional adjustments (e.g., because of \\
severe arguments). \\
\hline 9. Some behaviour is upsetting (e.g., crying, night awakenings). \\
\hline 10. It is upsetting to find the situation has changed so much compared \\
to before. \\
\hline 11. There have been work adjustments (e.g., because of having to take \\
time off). \\
\hline 12. It is a financial strain. \\
13. Feeling completely overwhelmed (e.g., because of concern about how \\
to care for your child). \\
Total Score (count yes responses) \\
\hline
\end{tabular}

\section{References}

1. Don, B.P.; Chong, A.; Biehle, S.N.; Gordon, A.; Mickelson, K.D. Anxiety across the transition to parenthood: Change trajectories among low-risk parents. Anxiety Stress Coping 2014, 27, 633-649. [CrossRef] [PubMed]

2. Lee, H.; Kim, K.-E.; Kim, M.-Y.; Park, C.G.; Han, J.Y.; Choi, E.J. Trajectories of Depressive Symptoms and Anxiety during Pregnancy and Associations with Pregnancy Stress. Int. J. Environ. Res. Public Health 2021, 18, 2733. [CrossRef]

3. Razurel, C.; Kaiser, B.; Sellenet, C.; Epiney, M. Relation between perceived stress, social support, and coping strategies and maternal well-being: A review of the literature. Women Health 2013, 53, 74-99. [CrossRef]

4. Hasanjanzadeh, P.; Faramarzi, M. Relationship between maternal general and specific-pregnancy stress, anxiety, and depression symptoms and pregnancy outcome. J. Clin. Diagn. Res. 2017, 11, VC04. [CrossRef] [PubMed]

5. Nelson, A.M. Transition to motherhood. J. Obstet. Gynecol. Neonatal Nurs. 2003, 32, 465-477. [CrossRef]

6. Zarit, S.H.; Birkel, R.C.; Malone-Beach, E. Family Involvement in the Treatment of the Frail Elderly; Goldstein, M.Z., Ed.; American Psychiatric Press: Washington, DC, USA, 1989.

7. Lazarus, R.S.; Folkman, S. Stress, Appraisal, and Coping; Springer Publishing Company: New York, NY, USA, 1984.

8. Kim, H.; Chang, M.; Rose, K.; Kim, S. Predictors of caregiver burden in caregivers of individuals with dementia. J. Adv. Nurs. 2012, 68, 846-855. [CrossRef] [PubMed]

9. Crespo, M.; López, J. El Estrés en Cuidadores de Mayores Dependientes. Cuidarse para Cuidar; Psicología Pirámide: Madrid, Spain, 2007.

10. Domingues, N.S.; Verreault, P.; Hudon, C. Reducing Burden for Caregivers of Older Adults with Mild Cognitive Impairment: A Systematic Review. Am. J. Alzheimer's Dis. Demen. 2018, 33, 401-414. [CrossRef] [PubMed]

11. del-Pino-Casado, R.; Espinosa, A.; Lopez, C.; Orgeta, V. Sense of coherence, burden and mental health in caregiving: A systematic review and meta-analysis. J. Affect. Disord. 2019, 242, 14-21. [CrossRef] [PubMed]

12. Cooper, C.; Balamurali, T.; Livingston, G. A systematic review of the prevalence and covariates of anxiety in caregivers of people with dementia. Int. Psychogeriatr. 2007, 19, 175-195. [CrossRef]

13. Britton, J.R. Maternal anxiety: Course and antecedents during the early postpartum period. Depress. Anxiety 2008, 25, 793-800. [CrossRef] 
14. Leung, S.S.; Martinson, I.M.; Arthur, D. Postpartum depression and related psychosocial variables in Hong Kong Chinese women: Findings from a prospective study. Res. Nurs. Health 2005, 28, 27-38. [CrossRef] [PubMed]

15. Geng, H.M.; Chuang, D.M.; Yang, F.; Yang, Y.; Liu, W.M.; Liu, L.H.; Tian, H.M. Prevalence and determinants of depression in caregivers of cancer patients: A systematic review and meta-analysis. Medicine 2018, 97, e11863. [CrossRef]

16. Watson, B.; Tatangelo, G.; McCabe, M. Depression and Anxiety among Partner and Offspring Carers of People with Dementia: A Systematic Review. Gerontologist 2019, 59, e597-e610. [CrossRef] [PubMed]

17. Zhu, W.; Jiang, Y. A Meta-analytic Study of Predictors for Informal Caregiver Burden in Patients with Stroke. J. Stroke Cerebrovasc. Dis. 2018, 27, 3636-3646. [CrossRef] [PubMed]

18. Nurbaeti, I.; Deoisres, W.; Hengudomsub, P. Association between psychosocial factors and postpartum depression in South Jakarta, Indonesia. Sex. Reprod. Healthc. 2019, 20, 72-76. [CrossRef] [PubMed]

19. Poo, F.A.; Espejo, S.C.; Godoy, P.C.; Gualda, C.M.; Hernandez, O.T.; Perez, H.C. Prevalence and risk factors associated with postpartum depression in puerperal women consulting in primary care. Rev. Med. Chil. 2008, 136, 44-52.

20. Shorey, S.; Yin, C.C.; Debby, E.; Yiong, C.; Wai, W.T.; Seng, C.Y. Prevalence and incidence of postpartum depression among healthy mothers: A systematic review and meta-analysis. J. Psychiatr. Res. 2018, 104, 235-248. [CrossRef]

21. Fiala, A.; Švancara, J.; Klánová, J.; Kašpárek, T. Sociodemographic and delivery risk factors for developing postpartum depression in a sample of 3233 mothers from the Czech ELSPAC study. BMC Psychiatry 2017, 17, 104. [CrossRef]

22. Marín-Morales, D.; Toro-Molina, S.; Peñacoba-Puente, C. Relationship between postpartum depression and psychological and biological variables in the initial postpartum period. Matern. Child Health J. 2018, 22, 866-873. [CrossRef]

23. Míguez, M.C.; Fernández, V.; Pereira, B. Depresión postparto y factores asociados en mujeres con embarazos de riesgo. Rev. Int. Psicol. Clin. Salud. 2017, 25, 47-64.

24. Escribà-Agüir, V.; Artazcoz, L. Gender differences in postpartum depression: A longitudinal cohort study. J. Epidemiol. Community Health 2011, 65, 320-326. [CrossRef]

25. Garcia, L.; Ascaso, C.; Ojuel, J.; Navarro, P. Validation of the Edinburgh postnatal depression scale (EPDS) in Spanish mothers. J. Affect. Disord. 2003, 75, 71-76. [CrossRef]

26. Odriozola, M.; Vita, A.; Maiz, B.; Zialtzeta, L.; Bengoetxea, L. Índice de esfuerzo del cuidador: Test diagnóstico de sobrecarga en cuidadores de enfermos con demencia. Semergen 2008, 34, 435-438. [CrossRef]

27. Robinson, B.C. Validation of a caregiver strain index. J. Gerontol. 1983, 38, 344-348. [CrossRef]

28. López, O.; Lorenzo, A.; Santiago, P. Morbilidad en cuidadores de pacientes confinados en su domicilio. Aten. Prim. 1999, 24, 404-410.

29. Gómez, M.J.; González, F.M. El cuidador del paciente con demencia: Aplicación del test Índice del Esfuerzo del Cuidador. Rev. Esp. Geriatr. Gerontol. 2004, 39, 154-159. [CrossRef]

30. Moral, M.S.; Ortega, J.J.; López, M.J.; Pellicer, P. Perfil y riesgo de morbilidad psíquica en cuidadores de pacientes ingresados en su domicilio. Aten. Prim. 2003, 32, 77-83. [CrossRef]

31. López, S.R.; Moral, M.S. Validación del Índice de Esfuerzo del Cuidador en la población española. Enferm. Comun. 2005, 1, 12-17.

32. Escurra, L. Cuantificación de la validez de contenido por criterio de jueces. Rev Psicol. 1988, 6, $103-111$.

33. Aiken, L.R. Three coefficients for analyzing the reliability and validity of ratings. Educ. Psychol. Meas. 1985, 45, 131-142. [CrossRef]

34. Feligreras-Alcalá, D.; Frías-Osuna, A.; del-Pino-Casado, R. Personal and Family Resources Related to Depressive and Anxiety Symptoms in Women during Puerperium. Int. J. Environ. Res. Public Health 2020, 17, 5230. [CrossRef]

35. Cox, J.L.; Holden, J.M.; Sagovsky, R. Detection of postnatal depression: Development of the 10-item Edinburgh Postnatal Depression Scale. Br. J. Psychiatry 1987, 150, 782-786. [CrossRef]

36. Buela, G.; Guillén, A.; Seisdedos, N. Manual del Cuestionario de Ansiedad Estado-Rasgo (STAI); TEA Ediciones: Madrid, Spain, 1982.

37. Antonovsky, A. The structure and properties of the sense of coherence scale. Soc. Sci. Med. 1993, 36, 725-733. [CrossRef]

38. Broadhead, W.E.; Gehlbach, S.H.; De-Gruy, F.V.; Kaplan, B.H. The Duke-UNC Functional Social Support Questionnaire: Measurement of social support in family medicine patients. Med. Care 1988, 26, 709-723. [CrossRef]

39. Ministry of Health, Social Services and Equality. Clinical Practice Guide for Pregnancy and Puerperium Care; Ministry of Health, Social Services and Equality: Madrid, Spain, 2014.

40. Guillén, A.; Buela, G. Actualización psicométrica y funcionamiento diferencial de los items en el State Trait Anxiety Inventory (STAI). Psicothema 2011, 23, 510-515.

41. Virués, J.; Martínez, P.; del Barrio, J.L.; Lozano, L.M. Validación transcultural de la Escala de Sentido de Coherencia de Antonovsky (OLQ 13) en ancianos mayores de 70 años. Med. Clin. 2007, 128, 486-492. [CrossRef]

42. Bellón, J.S.; Delgado, A.S.; del-Castillo, J.D.; Lardelli, P.C. Validity and reliability of the Duke-UNC-11 questionnaire of functional social support. Aten. Prim. 1996, 18, 153-163.

43. del-Pino-Casado, R.; Priego-Cubero, E.; López-Martínez, C.; Orgeta, V. Subjective caregiver burden and anxiety in informal caregivers: A systematic review and meta-analysis. PLoS ONE 2021, 16, e0247143. [CrossRef] [PubMed]

44. Peng, M.M.; Zhang, T.M.; Liu, K.Z.; Gong, K.; Huang, C.H.; Dai, G.Z.; Hu, S.H.; Lin, F.R.; Chan, S.K.; Ng, S.; et al. Perception of social support and psychotic symptoms among persons with schizophrenia: A strategy to lessen caregiver burden. Int. J. Soc. Psychiatry 2019, 65, 548-557. [CrossRef] [PubMed] 
45. George, D.; Mallery, P. SPSS for Windows Step by Step: A Simple Study Guide and Reference, 17.0 Update, 10th ed.; Allyn \& Bacon: Boston, MA, USA, 2010.

46. Fleiss, J.L. Reliability of Measurement. The Design and Analysis of Clinical Experiments; John Wiley and Sons: New York, NY, USA, 1986.

47. Frías, D. Apuntes de Consistencia Interna de las Puntuaciones de un Instrumento de Medida; Universidad de Valencia: Valencia, Spain, 2019.

48. Mandeville, P.B. El Coeficiente de Correlación Intraclase (CCI); Universidad Autónoma de Nuevo León: Nuevo León, Mexico, 2005.

49. Ugur, O.; Fadiloglu, C. Caregiver Strain Index validity and reliability in Turkish society. Asian Pac. J. Cancer Prev. 2010, 11, 1669-1675. [PubMed]

50. Ramasamy, M.S.; Ibrahim, R.; Madon, Z.; Arshat, Z. A validity study of Malay-translated version of the Modified Caregivers Strain Index Questionnaire (M-CSI-M). J. Bus. Soc. Rev. Emerg. Econ. 2017, 3, 217-226.

51. Chan, W.C.; Chan, C.L.; Suen, M. Validation of the Chinese version of the Modified Caregivers Strain Index among Hong Kong caregivers: An initiative of medical social workers. Health Soc. Work 2013, 38, 214-221. [CrossRef] [PubMed]

52. Ribeiro, O.; Brandão, D.; Oliveira, A.F.; Martín, I.; Teixeira, L.; Paúl, C. The Modified Caregiver Strain Index: Portuguese version. J. Health Psychol. 2019. [CrossRef]

53. Yébenes, M.; Rodríguez, F.; Carmona, L. Validación de cuestionarios. Reumatol. Clin. 2009, 5, 171-177.

54. Thornton, M.; Travis, S.S. Analysis of the reliability of the modified caregiver strain index. J. Gerontol. Soc. Sci. 2003, 58, 127-132. [CrossRef] [PubMed] 